\title{
Quality Requirements for Continuous Use of E-learning Systems at Public vs. Private Universities in Spain
}

\author{
Jana Prodanova* \\ jprodanova@ubu.es \\ Universidad de Burgos, Spain \\ Sonia San-Martín \\ sanmargu@ubu.es \\ Universidad de Burgos, Spain \\ Estefanía Jerónimo Sánchez-Beato \\ ejeronimo@uemc.es \\ Universidad Europea Miguel de Cervantes, Spain
}

\begin{abstract}
During the later years of technological innovation, e-learning systems have demonstrated to be an effective way to improve perceived educational quality and overcome time and place constraints. Virtual communication, instruction and evaluation have become an important part of higher education. However, although e-learning has been implemented extensively, its operation and success might differ between organisations due to institutional capacity and resources. With this in mind, the objective of this research is to distinguish between public and private universities, in the sense of the e-learning system quality and the perceived institutional support, as means to achieve users' intention to continue using e-learning. Analysing the information from 270 Spanish teachers and students in e-learning systems at public and private universities, we concluded that information, service, and perceived educational quality determine continuous e-learning use at public universities, while perceived institutional support acts as a mediator between the information and perceived educational quality and the continued use, in the case of the private universities. Valuable recommendations for higher-education institutions' management suggest that innovative tools for interaction and organisation, cooperation of public and private universities, and investment in technology and human resources are vital for continuity of e-learning systems.
\end{abstract}

\section{Keywords}

E-learning; public and private higher education; quality; institutional support; continuous use 


\section{Introduction}

Due to the innovation disruption and ICT (Information and Communication Technologies) that has significantly changed people's way of life, the education system has gone through a great transformation. In higher education particularly, virtual platforms and e-learning tools have been increasingly adopted to offer diversified teaching and learning experiences, bearing in mind ICT' potential to constantly and ubiquitously adapt teaching and learning strategies to users' needs and preferences (Raposo-Rivas and de la Serna, 2019). E-learning is the crucial innovation of nowadays educational systems, essential for both public and private universities, considered to provide a high level of positive experience through the quality of the service, the creativity of the offer, management of the organisation and problem-solving abilities (Al-Husseini and Elbeltagi 2016). Defined "as a tool that uses computer network technology such as internet, intranets and extranets to deliver learning instructions to users" (Abdullah and Ward 2016, 238), e-learning systems combine instructional materials in different media forms, such as audio, video and text, which are made available online for consultation and discussion, with the means of improving the learning and evaluation process (Lee et al. 2011).

E-learning has been considered especially applicable in situations of inaccessibility because of remoteness (rural areas) or personal disability (disease problem), and even in critical circumstances, such as limited movement due to isolation (COVID-19 quarantine) or war-affected zones (armed conflicts in Asia or Africa) (Arheiam 2019; Chatterjee et al. 2020; Fichten et al. 2020). However, entirely implementing an e-learning system largely depends on the institutional economic and managerial capacity, which can be recognised in the distinct e-learning implementation rates of public and private higher-education institutions. For instance, in Spain, as one of the countries with the highly developed educational private sector (32 private universities out of 82 currently active universities), only one public university has completely adopted elearning, while five private universities offer exclusively e-learning courses (MCIU 2019). Regarding the partial implementation of e-learning, private universities seem to more extensively implement it, handling more than half of the graduate and post-graduate courses online.

Triggered by these facts, we contemplate in this study users' perception of the e-learning system in public and private universities, with the idea of detecting similarities and differences in the influencing factors of e-learning continued usage. For this purpose, following a relevant body of knowledge, we propose a treble objective: (a) to study the influence of e-learning quality elements -system, information, service, and perceived educational quality-, on continuous usage and perceived institutional support; (b) to determine how the perceived institutional support impacts users' intention to continue using the e-learning system; (c) to identify the differences in these relations $(a, b)$ between public and private universities.

With this in mind, next is elaborated the theoretical background that serves as a foundation to propose the research hypotheses (Section 2). Then, a detailed empirical study is presented with information collected from teachers and students and treated with Partial Least Squares Structural Equations Modelling (PLS-SEM) regarding e-learning systems' users at public and private universities (Section 3). Finally, relevant findings and implications of international interest, driven from the results of this research, are summarised (Section 4). This study is a valuable contributor to the e-learning literature and practice, observing e-learning quality from four different perspectives (system, information, service and educational) as the crucial elements towards the achievement of positive perceptions regarding the institutional support and favourable attitudes related to the continuous use of e-learning. Moreover, practical recommendations for both public and private universities uphold the investigation importance. 


\section{Theoretical background}

In the late years, the ICT potential induced by technological innovations has made highereducation institutions recognise the capacity of e-learning systems in the way to creatively improve the teaching and learning process. They have invested in various technological tools, virtual platforms and educational approaches that have brought a difference in the quality of satisfying users' needs and preferences (Evans et al. 2020). It has been stated in the literature that the information systems applied to the field of higher education must be versatile and must adapt to the educational context by providing a variety of functionalities that would make the e-learning process valuable (Mohammadi 2015).

The adaptability of the e-learning system to the learning and teaching style highly depends on the availability of resources integrated into the system (Vernadakis et al. 2011). Therefore, despite the existence of various tools, e-learning not always is applied successfully. Some of the reasons might be found in the lack of knowledge or familiarity, inexperience, or shortage in personal or institutional resources for the suitable implementation and development of e-learning (FernándezQuero 2021). Hence, the e-learning quality cannot be directly deduced from the mere implementation of new technologies. Thus, it is vital to promote a technological culture in the attempt to adapt better the teachers and students' skills, especially important due to the recent Covid-19 emergency, as the means for reducing the impact of the pandemic on the necessary adaptations of practices regarding working and studying from home (de la Iglesia Villasol 2021).

In the e-learning research, the concept of quality has been considered as a key determinant to achieve adoption and use of the e-learning system (Martínez-Argüelles and Batalla-Busquets 2016; Pham et al. 2018). Explored from different perspectives, including e-learning providers, assessors, professionals or users (Jung, 2011), most frequently, the quality has not been recognised as the sole variable, yet different components have been distinguished that would compose the overall quality of the e-learning system (Almutairi and Albraithen 2018). Some of the most commonly observed are the system quality, the content quality, the system interactivity, the perceived usefulness and ease of use, the system flexibility, the possibility for training and technical support.

Consistent with the previous, since the beginning of the pandemic, teachers and students had to adapt to the new way of digitally based schooling. In the attempt to mitigate the negative effects of the Covid-19 crisis on both parties, new ways of knowledge management have emerged (Velásquez and Lara 2021). The low-income and minority population were found disadvantaged in accessing hardware and software technologies to support teaching and learning, and parents who served as essential workers were unable to supervise and assist their children attempting to learn remotely (Gandolfi et al. 2021). For teachers, this meant designing methodological strategies and online resources without sufficient time for the technical validation of the suitability of the same and constructing evaluation methods for virtually measuring knowledge and skills (de la Iglesia Villasol 2021). Consequently, e-learning in times of pandemic has been operating based on teachers and students' own intuition, instead guided by a reference pedagogical model (Prensky 2013; Bates 2015; de la Iglesia Villasol 2021). The latest occurrence, in line with the current knowledge, has underlined the obligation to precisely differentiate the main quality elements that trace the continued use of e-learning, contributing to the implementation of the Information Systems Continuance Model (ISCM) (DeLone and McLean 1992; Bhattacherjee 2001). It has emphasised the necessity for an enduring use of an e-learning system, not only its initial adoption, in order for this to be considered successful (Kang and Lee 2010; Lin 2012; Ifinedo 2017). Namely, even though the initial acceptance of an e-learning system is essential for its success, its ongoing sustainability depends on its continued use (Al-Samarraie et al. 2018). Accordingly, the ISCM proposes that the quality in e-learning can be specified by system quality, information quality, service quality and perceived educational quality as the basics in the achievement of effective use of the e-learning system (Ćukušić et al. 2010; Mohammadi 2015). Therefore, in this study, the 
focus is put on the effect of these e-learning quality elements on the continued use of the elearning system.

However, these are not the unique factors that are supposed to influence the e-learning continued use. Precisely, students' satisfaction, instructors' quality, institutional support, have been contemplated as important factors, as well (Al-Samarraie et al. 2018; Almutairi and Albraithen 2018). When it comes to the observation of the public vs private sector of higher education, institutional support is believed to be the point of inflexion (Naidu and Derani 2016; Mushtaq and Malik 2018). Institutional support has been described as the organisational effort towards and support of e-learning activities, such as financial, technical or human resource support, acknowledgement and feedback of time and involvement invested in the development and maintenance of the e-learning system and process, and creating opportunities for enhancing teachers' skills and progressing students' learning evolution (Nijman and Gelissen 2011; McGill et al. 2014; Johnson et al., 2019). As a matter of fact, institutional support has been considered as the crucial element in the achievement of continuous e-learning implementation and use in highereducation institutions (Gunn 2010; McGill et al. 2014).

Consequently, the study exploration has been extended to consider, likewise, the role of the institutional impact in the process of accomplishing a continued use of the e-learning system, distinguishing between public and private universities cases. To the extent of our knowledge, there is no research on this issue of public vs private e-learning antecedents and impact.

\section{Research hypotheses}

Constituting elements of the overarching concept of quality are system, information, service and perceived educational quality. Each element is specifically defined in the literature. That is, previous research has described systems quality in terms of operational characteristics such as system reliability and stability, interface consistency and interactivity, which make the e-learning system more sustainable (McGill et al. 2014), including design aspects, such as attractiveness and optimal navigation (Uppal et al. 2018). The information quality of the learning and teaching process represents the ability of the system to provide useful and reliable content, presented in a structured way, emphasising the comprehensiveness and flow of the information (Mohammadi 2015; Aparicio et al. 2017; Uppal et al. 2018). The service quality reflects the support that users receive when using the e-learning system, such as technical assistance, help regarding the system adoption and management, or training to facilitate the system use (Petter and McLean 2009; Wang and Chiu 2011). The perceived educational quality of the e-learning system is defined as the ability of the system to provide a conducive learning environment for its users, meaning that it assesses the factors that make possible the creation of encouraging learning and teaching environment and contribute to making it as collaborative as possible (Wang and Chiu 2011; Kim et al. 2017). Keeping in mind this explanation, following are developed the proposed hypotheses to determine the relationships describing the quality effects and the respective contributions on the e-learning system usage and perceptions.

\section{a. System quality}

The system quality is of crucial importance for the continued use of the e-learning system, and it is a facilitating condition leading to e-learning system sustained use. Users perceiving high system quality of the e-learning system are expected to develop positive attitudes towards the system and to have a greater intention to continue using the system (Al-Samarraie et al. 2018). Therefore, an 
e-learning system that provides efficient teaching and learning through suitable instructions and enables optimised communication among the users will positively influence users' intentions of continuous system use ( $\mathrm{Li}$ et al. 2012). Moreover, the degree of investment by the institution in resources dedicated to a user-friendly environment, technical structure and reliability, and support to users' interaction and participation, which facilitates the use of and access to the e-learning systems, are vital to the perceived institutional support (Khan et al. 2017; Almutairi and Albraithen 2018). Therefore, it is assumed that:

H1: System quality positively influences (a) the intention to continue using the e-learning system and (b) the perceived institutional support.

\section{b. Information quality}

E-learning system scoring high in information quality is represented by information accuracy, timeliness, scope, completeness, relevance and consistency provided by the system and is expected to enhance users' positive attitudes and intentions towards a continued usage (Delone and McLean 2003; Al-Samarraie et al. 2018). The correctness of the information and satisfactory content, according to users' needs, is vital for system usage (Kurt 2019). Moreover, the highereducation institutions have a crucial role in providing users with resources to assure an organised and clearly presented teaching and learning content, as means of acknowledging their support in users improved knowledge and skills (Wu and Lin 2012). Accordingly, the relevance of the information and the access to it, assured by the university, evidence the perceived institutional support in the continuous improvement of the e-learning system (Kettunen 2008). Therefore, the next hypothesis is proposed:

H2: Information quality positively influences (a) the intention to continue using the e-learning system and (b) the perceived institutional support.

\section{c. Service quality}

An e-learning service quality, which enables the technology to provide users with good course management, suitable learning materials and explanations, or the possibility to share opinions and insights between the users of the e-learning system, positively affects users' perceptions and their intention to continue using the e-learning system (Wang and Liao 2008; McGill and Klobas 2009; Mohammadi 2015; Aparicio et al. 2017; Al-Samarraie et al. 2018). That is why institutions' management of the e-learning service quality is essential. Higher-education institutions must competently provide resources that will guarantee comprehensive learning and cooperative participation in the e-learning system (Wu and Lin 2012) so that their support is recognised. Consequently, the following hypothesis is suggested:

H3: Service quality positively influences (a) the intention to continue using the e-learning system and (b) the perceived institutional support.

\section{d. Perceived educational quality}

The use of ICT in the education process is fundamental in boosting communication and collaboration between the users of the system (Williams and Beam 2019). This could be represented by the use of chats, forums or other tools, which would enable feedback and support for both teachers and students (Queiros and de Villiers 2016; Hadullo et al. 2018). The perceived educational quality is found to have characteristics beneficial for the e-learning system users and their usage intentions (Hassanzadeh et al. 2012; Mohammadi 2015). Regarding the higher- 
education institution role in the e-learning process, in order for users to identify the organisational support, universities have to offer to users applicable teaching and learning strategies and relevant teaching/learning style that instigates feedback, evaluation and communication (Wu and Lin 2012). Accordingly, the following is hypothesised:

H4: Perceived educational quality positively influences (a) the intention to continue using the elearning system and (b) the perceived institutional support.

\section{e. The link between perceived institutional support and continuous usage}

It has been confirmed in the literature that higher-education institutions have a decisive position in e-learning system enactment (Khan et al. 2017; Almutairi and Albraithen 2018). The institutional effort and investment in e-learning system infrastructure are considered key to the success of this innovation. Precisely, the continued use of e-learning has been influenced by the level of institutional support in endorsing e-learning innovation initiatives and continued implementation, providing ongoing financial and technical support, and recognising colleagues' assistance (Wang et al. 2007; Gunn 2010; McGill et al. 2014). Accordingly, users' perception of institutions' support in the maintenance of the e-learning network, contributing with economic, technological or human resources (Hadullo et al. 2018), is essential for their intentions to continue using the e-learning system. This means that as long as the institution invests in the required resources that would deliver an advantage, the intention to continue using e-learning is likely to take place. Therefore, it is proposed that:

H5: The perceived institutional support positively influences the intention to continue using the elearning system.

\section{f. Public vs private universities comparison}

The education-related body of knowledge has scarcely explored the differences between the public and private institutions. Certain research suggests that quality outcomes and efficiency at public universities might differ from those of private education, where the first seek to provide a better service quality, and the second are more focused on maximising profits (Rey and Romero 2004). Moreover, dissimilarities have been detected in the quality and efficiency of public and private universities' educational service, in terms of teaching/learning contents and system technology because of institution's resources availability and conditions (Wilkinson and Yussof 2005; Naidu and Derani 2016). This situation can cause users' different perceptions of the service provided by public and private universities, which is why the next postulation is proposed:

H6: The proposed relationships will be different for e-learning users coming from public vs private universities.

All the hypotheses reasoned in detail above can be summarily observed in Figure 1. 


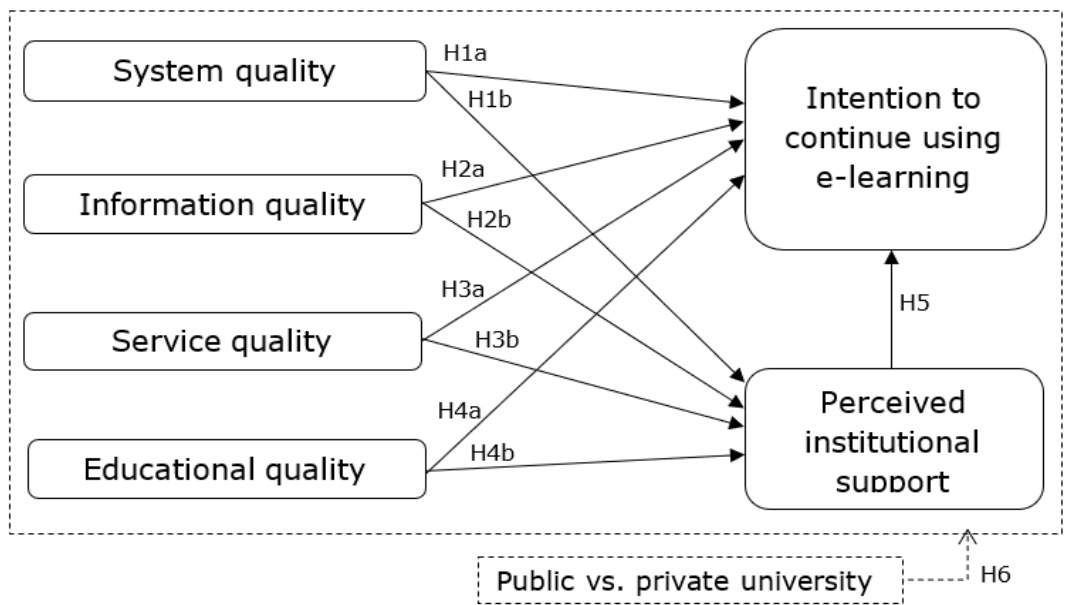

Figure 1. Proposed research model Source: Own elaboration

\section{Methodology}

\section{a. Procedure and sample}

In this investigation it was applied a quantitative method of research, designing a survey that would reflect participants' perceptions and preferences. The contemplated variables were measured by validated scales from the previous literature, which have been adapted to the context of this research. The scales have their base in different studies for the system, information, service and perceived educational quality (Mohammadi 2015), perceived institutional support (McGill et al. 2014) and intention to continue using e-learning (Kang and Lee 2010). A pre-test with 5 experts in the field and 20 current users of e-learning platforms resolved minor survey problems and assured questions' comprehensibility. 5-point Likert scales were implemented to measure the variables.

A non-probabilistic sampling method, precisely purposive sampling, was applied. This approach was considered appropriate, given the specific predefined group of teachers and students of e-learning (Tashakkori and Teddlie, 2010). Two Spanish universities, one public and one private, participated in the survey. The primary learning system in both is implemented offline, but online teaching has been increasingly adopted. Information gathering was carried out in two stages. First, all online teachers from the two universities were nominated to conduct the survey. Second, those who answered the questionnaire were also asked to invite their online students to join the study.

Using personal questionnaires as a method of data collection, information from 270 users of elearning systems at those two Spanish universities was collected. It included teachers $(45.9 \%)$ and students $(54.1 \%)$ of e-learning systems at public (54.4\%) and private universities (45.6\%). PLSSEM approach was applied for the model estimation (Hair et al. 2017).

\section{b. Findings}

Harman's single-factor test (Podsakoff et al. 2003) was employed to test the common method bias. Following the literature (Fuller et al. 2016), we concluded that no problem of common variance is recognised. The exploratory factor analysis confirmed that all items loaded into one factor explain $33.01 \%$ of the data variance, while the cumulative variance explained by all factors was $58.35 \%$.

In the process of estimating the proposed model, the formative (system, information, service and 
perceived educational quality, and perceived institutional support) and reflective (intention to continue using e-learning) measurement variables showed statistically significant values at a confidence level of $95 \%$ ( $t>1.96$ ), for weights and loadings coefficients, correspondingly. Refining the scales, three items (one from information quality and two from perceived educational quality) had to be deleted due to statistically non-significant $t$-Values. Then, for the reflective variable, the reliability and internal consistency of the scales was corroborated by Cronbach alpha $(a>0.7)$ and composite reliability ( $C R>0.6)$ coefficients, and next, the convergent validity was confirmed by the average variance extracted (AVE>0.5) (Bagozzi and Yi 1988). Besides, for the formative variables, the multicollinearity of the model was discarded by the Variance Inflation Factor (VIF $<5)$ and the Tolerance Value (IT> 0.1) (Diamantopoulos and Winklhofer 2001; Hair et al. 2017). Lastly, following the Heterotrait-Monotrait Ratio $($ HTMT<0.9) (Henseler et al. 2015), the discriminant validity between all the constructs was as well confirmed. All of this can be observed in Table 1.

\section{Construct name and measurement items}

\section{System quality}

The e-learning platform:

Is appealing.

Optimizes response time.

Is user-friendly.

Provides interactive features between users and the system.

Possesses a structured design.

Has flexible features.

Has attractive features.

Is reliable.

Is safe.

\section{Information quality}

E-learning provides:

Information that is relevant to users' needs.

Complete information.

Information required by users.

Organised content.

Content required by the users.

\section{Service quality}

E-learning provides:

Adequate online assistance and explanation.

Distance cooperative teaching/learning a .

Opportunity for reflection on views. 
Good course management.

Perceived educational quality

E-learning provides:

Incentives to users. 600

Collaborative teaching/learning a.

Possibility to communicate with other users.

E-learning corresponds to a good teaching/learning a style.

Perceived institutional support

The University:

Supports the continuity of this innovation.

Supports the initiatives of innovation in e-learning.

Provides economic resources for the development of this innovation.

Provides technical resources for the development of this innovation.

There are human resources for the ongoing development of this innovation.

This innovation represents a competitive advantage for the university.

Intention to continue using e-learning ( $\mathrm{AVE}=.751 ; a=.830 ; C R=.900)$

$\boldsymbol{\lambda}$

I would like to continue using e-learning.

My intentions are to continue using e-learning.

I prefer using online to offline teaching/learning ${ }^{a}$.

Table 1. Measurement model estimation

Note: *All weights and loadings are statistically significant $(p<0.05) ;{ }^{a}$ In some items, a distinction is made between teaching and learning activities due to the occupation of the survey respondent, i.e. teacher or student.

Before observing the relationships in the global model, it was confirmed that the $\mathrm{R}^{2}$ of the dependent variables exceeds 0.1 (Falk and Miller 1992). Consequently, the $R^{2}$ value for the perceived institutional support is 0.524 and for the intention to continue using e-learning is 0.346 . The fulfilment of 7 out of 9 proposed hypotheses was next corroborated (Table 2). Therefore, service quality and perceived educational quality influence both the institutional support as perceived by users and their intentions to continue using the system. System quality and information quality impact only the perceived institutional support, which, in turn, has a positive effect on users' intentions to continue with the e-learning system use.

\section{Hypothesised relationships}

Coefficient

$\boldsymbol{\beta}$

t Value

H1: System quality positively influences:

(a) intention to continue using the e-learning system. 
(b) perceived institutional support.

H2: Information quality positively influences:
(a) intention to continue using the e-learning system.
(b) perceived institutional support.
.298

H3: Service quality positively influences:
(a) intention to continue using the e-learning system.
.213
(b) perceived institutional support.
.174

H4: Perceived educational quality positively influences:
(a) intention to continue using the e-learning system.
.235
$2.764^{*}$
(b) perceived institutional support.
.261
H5: The perceived institutional support positively influences the intention to continue using the e-learning system.

Table 2. Causal model estimation

Note: ${ }^{*} \mathrm{p}<0.05 ; \mathrm{ns}=$ not significant.

To address H6, a multi-group model was estimated, identifying the different perspectives for the two types of institutions: public and private universities. The two groups have similar sizes. 147 users $(54.4 \%)$ come from public universities and 123 individuals $(45.6 \%)$ come from private universities. Following the Welch-Satterthwait test for multi-group analysis, results show that the type of institution moderates some of the proposed relationships of several quality elements, the perceived institutional support and the intention of the users to continue using the e-learning system (Table 3).

\begin{tabular}{|l|l|l|l|}
\hline \multirow{3}{*}{ Path } & $\boldsymbol{\beta}$ (Public & $\boldsymbol{\beta}$ (Private & Welch- \\
& University) & University) & Satterthwait \\
& $/$ t-value & / t-value & Test t-Value \\
\hline
\end{tabular}

H1: System quality positively influences:
(a) intention to continue using the e- learning system.
$-.065 / .610^{\mathrm{ns}} \quad .004 / .024^{\mathrm{ns}} \quad .343^{\mathrm{ns}}$
(b) perceived institutional support.
$.151 / 1.177^{\text {ns }} \quad .152 / 1.685^{* *} \quad .007^{\text {ns }}$

H2: Information quality positively influences:
(a) intention to continue using the e- learning system.
$.230 / 2.442^{*}-.067 / .483^{n s}$
$1.783 * *$
(b) perceived institutional support.
$.275 / 2.386 * \quad .361 / 3.513^{*} \quad .555^{\mathrm{ns}}$

H3: Service quality positively influences:
(a) intention to continue using the e- learning system.
(b) perceived institutional support. 
H4: Perceived educational quality positively influences:

\begin{tabular}{llll}
\hline $\begin{array}{l}\text { (a) intention to continue using the e- } \\
\text { learning system. }\end{array}$ & $.367 / 3.898^{*}$ & $-.080 / .642^{\mathrm{ns}}$ & $2.875^{*}$ \\
$\begin{array}{l}\text { (b) perceived institutional support. } \\
\text { H5: The perceived institutional support }\end{array}$ & $.142 / 1.301^{\mathrm{ns}}$ & $.407 / 4.573^{*}$ & $1.883^{* *}$ \\
$\begin{array}{l}\text { positively influences the intention to } \\
\text { continue } \text { using the e-learning system. }\end{array}$ & $.016 / .175^{\mathrm{ns}}$ & $.579 / 4.094^{*}$ & $3.358^{*}$ \\
\hline
\end{tabular}

Table 3. Multi-group analysis and Welch-Satterthwait Test Note: $* p<0.05 ; * * p<0.01 ; \mathrm{ns}=$ not significant.

Regarding the multi-group analyses, it can be observed that a significant difference is found in $\mathrm{H} 2 \mathrm{a}, \mathrm{H} 3 \mathrm{~b}, \mathrm{H} 4 \mathrm{a}, \mathrm{H} 4 \mathrm{~b}$ and $\mathrm{Hb}$, underlining especially the relations where institutional support is involved.

However, if we look separately into the distinction between public and private universities, it can be specifically concluded that at public universities, the information quality $(\mathrm{H} 2 \mathrm{a})$, the service quality $(\mathrm{H} 3 \mathrm{a})$ and the perceived educational quality $(\mathrm{H} 4 \mathrm{a})$ are perceived as more important for achieving a continuous use of the e-learning system, something that does not at all happen for the case of the private universities.

When it comes to institutional support, there is a slightly different situation, where: (a) at public universities, it is the information $(\mathrm{H} 2 \mathrm{~b})$ and service quality $(\mathrm{H} 3 \mathrm{~b})$ that influence the perceived institutional support, and (b) at private universities there is the system ( $\mathrm{H} 1 \mathrm{~b})$, information $(\mathrm{H} 2 \mathrm{~b})$ and perceived educational quality $(\mathrm{H} 4 \mathrm{~b})$ that are necessary for the perception of institutional support to take place. For private universities, the perceived institutional support distinctively influences the intention towards continuous use (H5).

Therefore, the crucial finding here is that at public universities, the continuous use of the system would depend on its quality, while at private universities, the same would be determined by the perceived institutional support, which was likewise supported by the mediation analysis indicated previously.

Finally, bearing in mind the structure of the proposed model, naturally raises the need to estimate the mediating effect of the perceived institutional support (Table 4). Therefore, following recommendations by Baron and Kenny (1986), the significance of the relationships was verified with and without the mediating variable. Then, the indirect effects between the independent variables and the continuance intention were estimated. Accordingly, it could be concluded that the perceived institutional support acts as a mediator in the case of information and perceived educational quality.

\begin{tabular}{ll}
\hline Relationships & \\
\hline Mediator excluded & path $(t$ Value $)$ \\
\hline System quality $\rightarrow$ Continuance intention & $0,086(1,100)^{\text {ns }}$ \\
Information quality $\rightarrow$ Continuance intention & $0,200(3,054)^{*}$ \\
Service quality $\rightarrow$ Continuance intention & $0,202(2,624)^{*}$
\end{tabular}




\begin{tabular}{ll}
$\begin{array}{l}\text { Perceived educational quality } \rightarrow \text { Continuance } \\
\text { intention }\end{array}$ & $0,226(2,953)^{*}$ \\
\hline Mediator included & path $(t$ Value $)$ \\
\hline System quality $\rightarrow$ Continuance intention & $-.144(1.626)^{\mathrm{ns}}$ \\
System quality $\rightarrow$ Institutional support & $.133(2.394)^{*}$ \\
Information quality $\rightarrow$ Continuance intention & $.114(1.423)^{\mathrm{ns}}$ \\
Information quality $\rightarrow$ Institutional support & $.298(4.066)^{*}$ \\
Service quality $\rightarrow$ Continuance intention & $.213(2.609)^{*}$ \\
Service quality $\rightarrow$ Institutional support & $.174(2.130)^{*}$ \\
Perceived educational quality $\rightarrow$ Continuance & $.235(2.764)^{*}$ \\
intention & $.261(3.557)^{*}$ \\
Perceived educational quality $\rightarrow$ Institutional support & path $(t$ Value $)$ \\
\hline Indirect effect & $0,022(1,280)^{\mathrm{ns}}$ \\
\hline System quality $\rightarrow$ Continuance intention & $0,050(1,703)^{* *}$ \\
Information quality $\rightarrow$ Continuance intention & $0,029(1,401)^{\mathrm{ns}}$ \\
Service quality $\rightarrow$ Continuance intention & $0,043(1,697)^{* *}$ \\
Perceived educational quality $\rightarrow$ Continuance & \\
intention &
\end{tabular}

Table 4. Mediation effects of the perceived institutional support Note: ${ }^{*} \mathrm{p}<0.05 ; * * \mathrm{p}<0.01 ; \mathrm{ns}=$ not significant.

Following are discussed the obtained results, together with the contributions of this research, suggesting avenues for an improved e-learning system usage.

\section{Discussion and conclusions}

This study's objectives were to explore how the perception of different quality elements could influence users' perception of institutional support and their intentions towards a continuous use of the e-learning system. Both teachers and students were considered as users, and the dynamic at public and private universities was contemplated in the attempt to compare two types of institutions.

The results of this research show that for both types of institutions observed together, service quality, perceived educational quality and perceived institutional support of the e-learning system all have a positive effect on users' intention towards continued use of the system. These findings partly coincide with the literature, which does not present a consensus. As a matter of fact, certain research confirms quality elements' influence on e-learning-related behavioural intentions (Ameen et al. 2019; Kurt 2019), and, contrary, other shows dissimilar results unable to affirm these relations (Cidral et al. 2018; Yakubu and Dasuki 2018). The results may be conditioned by the elearning management and the level of implementation of the system, something that raises questions for further comparison and analyses of the existing literature. 
Moreover, all four quality elements favourably influence perceived institutional support. System quality does not make a significant difference in the perception of institutional support and continuance intentions, in neither observed case of the comparison between public and private universities. This may be because nowadays, the universities are using homogenised virtual platforms that are organised similarly based on Moodle platforms, already familiar to the users (Chung and Babin 2017). Consequently, considering Herzberg's dual-factor theory, it is likely that users perceive the system quality as a hygiene factor that identifies the working conditions, thus not motivating further positive perceptions or behaviours (Herzberg et al. 1959).

Contemplating the moderating effect of the institution type, we have found some interesting outcomes. Namely, information quality, service quality and perceived educational quality are deemed as substantial predictors of the e-learning system continued use at public universities. Information and perceived educational quality are crucial for institutional support to be perceived in the case of private universities. Additionally, without perceived institutional support at private universities, it cannot be expected to achieve a continuing system use, given that the earlier acts as a mediator between the information/perceived educational quality and the intention to continue using the system. The importance of the perceived institutional support at private universities must be highlighted because of the general impression that private educational institutions are more competitive than public ones, usually depending on private financing (Pucciarelli and Kaplan 2016).

This study adds value to the existing e-learning body of knowledge. It is unique research that considers extensive quality aspects and perceived institutional support in public vs private universities as a means for continuous use of an e-learning system. By a detailed exploration of the four quality elements, describing users' perceptions of the system, information, service and education provided through e-learning, this work identifies the necessary elements for users to perceive the university contribution in the e-learning process and system and for continued use of the same to be assured by teachers and students from both public and private universities. Bearing in mind that the Covid-19 pandemic has put the whole educational system to the test, the difficulties that teachers and students face due to the implementation of technology have turned more visible (de la Iglesia Villasol 2021). Thus, this is where a comprehensive analysis of the elearning system shows its input, detailing the elements that enrich the perception of successful elearning implementation and development.

Moreover, the managerial implications of this research can be summarised in the following way. First, the results suggest that public universities should focus on: a) the offer of organised, relevant and up-to-date information; b) the effective management of courses to promote instructional resources and sharing opinions, using innovative managerial and communication tools and apps (e.g., ProofHub, Tiny Letter, Skype, Dropbox, GoToMeeting); c) the collaborative and interactive teaching and learning, encouraging the application of gamification components, to directly increase possibilities for continued use of the e-learning system. Second, private universities must provide high-quality teaching materials, suitable assessments and feedback, and learning comprehension and interaction as a condition for the perceived institutional support that would, in turn, lead towards a continued e-learning system use. With the aim to more easily employ these materials and methods, public universities should share their findings and recommendations on educational resources, offering a state-of-the-art practical implementation of theoretical knowledge. Third, the operating interface (e-learning platform) seems not to be noteworthy, probably because users are already used to ICT interaction in everyday life. The employment of innovative tools and materials for interaction and communication could be a way of recognising the quality of the system. Fourth, universities' investment in technology, human resources, innovation and funding, will be perceived as a pertinent factor for the continued use of the e-learning system, especially at private universities. In line with this, it would be convenient for 
each university to perform a SWOT analysis and benchmarking to identify its own and the strengths of the competitors and try to learn from other institutions' good practices.

All of those activities would qualify an e-learning system appropriate to satisfy users' needs not only for distance education but for users in different situations of isolation, remoteness or even critical conditions regarding human health or security, without the vulnerability of finding their studying/teaching process interrupted. Moreover, these recommendations could be employed in the development of e-learning as part of lifelong learning systems, emphasising the exigency of users' digital competence (Dias-Trindade and Moreira, 2019).

\section{Limitations and future research lines}

Some of the limitations in this research derive from observation of universities only, instead of different educational institutions, and a consideration of the perceptions by teachers and students together, rather than distinguishing them. Therefore, in future research, an extended investigation of other educational institutions can be addressed, and a comparison of teachers and students separately from public and private universities can be proposed. The proposed extension will contribute to overcoming the limited generalizability created due to the observation of two universities by accomplishing a more comprehensive sample of entities. Moreover, contemplating other factors that could be associated with these relationships, such as the organisational structure, users' personality aspects or perceived value, or the precise circumstance when the elearning system is adopted, could provide enriching outcomes. Furthermore, given the deficiency of literature dedicated specifically to Spanish public and private universities' comparison, the global body of knowledge regarding higher-education institutions was primarily consulted in this study. Therefore, a more thorough exploration should be made of relevant studies about the Spanish higher-education system, including qualitative or even secondary data exploration. Finally, it would be valuable to replicate the study to compare the pre-Covid-19 and the post-Covid-19 tendency of e-learning and observe the success and compliance of the applied changes as a strategy to improve the system in the long term.

\section{References}

Abdullah, F., \& Ward, R. (2016). Developing a General Extended Technology Acceptance Model for E-Learning (GETAMEL) by analysing commonly used external factors. Computers in Human Behavior, 56, 238-256. doi:10.1016/j.chb.2015.11.036.

Al-Husseini, S., \& Elbeltagi, I. (2016). Transformational leadership and innovation: a comparison study between Iraq's public and private higher education. Studies in Higher Education, 41(1), 159-181. doi: $10.1080 / 03075079.2014 .927848$.

Al-Samarraie, H., Teng, B. K., Alzahrani, A. I., \& Alalwan, N. (2018). E-learning continuance satisfaction in higher education: a unified perspective from instructors and students. Studies in Higher Education, 43(11), 2003-2019. doi:10.1080/03075079.2017.1298088

Almutairi, B. M., \& Albraithen, M. A. (2018). A Framework on the Critical Success Factors of Virtual School System Implementation: A Systematic Literature Review. In 2018 1st International Conference on Computer Applications \& Information Security (ICCAIS) (pp. 1-6). IEEE.

Ameen, N., Willis, R., Abdullah, M. N., \& Shah, M. (2019). Towards the successful integration of e-learning systems in higher education in Iraq: A student perspective. British Journal of Educational Technology, 50(3), 1434-1446. doi:10.1111/bjet.12651

Aparicio, M., Bacao, F., \& Oliveira, T. (2017). Grit in the path to e-learning success. Computers in Human Behavior, 66, 388-399. doi:10.1016/j.chb.2016.10.009 
Arheiam, A. A., El Tantawi, M., Al-Omami, M., Peeran, S. W., \& Elmisalati, W. (2019). Perceptions of Stress Among Dental Students Living in a War-Affected Zone. Journal of dental education, 83(1), 48-55. doi: $10.21815 /$ JDE.019.006

Bagozzi, R. P., \& Yi, Y. (1988). On the evaluation of structural equation models. Journal of the academy of marketing science, 16(1), 74-94. doi:10.1007/BF02723327

Baron, R. M., \& Kenny, D. A. (1986). The moderator-mediator variable distinction in social psychological research: Conceptual, strategic, and statistical considerations. Journal of personality and social psychology, 51(6), 1173-1182. http://webcom.upmfgrenoble.fr/LIP/Perso/DMuller/GSERM/Articles/ Journal\%20of\%20Personality\%20and\%20Social\%20Psychology\%201986\%20Baron.pdf

Bates, A.W. (T) (2015). Teaching in a Digital Age: Guidelines for designing teaching and learning for a digital age. University of British Columbia. https://opentextbc.ca/teachinginadigitalage/

Bhattacherjee, A. (2001). Understanding information systems continuance: an expectation-confirmation model. MIS Quarterly, 25(3), 351-370. doi:10.2307/3250921

Chatterjee, A., Ghosh, K., \& Chatterjee, B. (2020). A Study on Content Selection and Cost-Effectiveness of Cognitive E-Learning in Distance Education of Rural Areas. In Emerging Technology in Modelling and Graphics (pp. 783-786). Springer, Singapore. doi:10.1007/978-981-13-7403-6_69

Chung, C., \& Babin, L. A. (2017). New technology for education: Moodle. In The Customer is NOT Always Right? Marketing Orientationsin a Dynamic Business World (pp. 661-661). Springer, Cham.

Cidral, W. A., Oliveira, T., Di Felice, M., \& Aparicio, M. (2018). E-learning success determinants: Brazilian empirical study. Computers \& Education, 122, 273-290. doi:10.1016/j.compedu.2017.12.001

Ćukušić, M., Alfirević, N., Granić, A., \& Garača, Ž. (2010). e-Learning process management and the e-learning performance: Results of a European empirical study. Computers \& Education, 55(2), 554-565. doi: $10.1016 /$ j.compedu.2010.02.017

de la Iglesia Villasol, M. C. (2021). Cambios en el patrón de los usos digitales por el Covid-19. Aplicación del Learning Analytics a un estudio de caso entre estudiantes universitarios. Digital Education Review, (39), 192-212.

DeLone, W. H., \& McLean, E. R. (1992). Information systems success: The quest for the dependent variable. Information systems research, 3(1), 60-95. doi:10.1287/isre.3.1.60

DeLone, W. H., \& McLean, E. R. (2003). The DeLone and McLean model of information systems success: a tenyear update. Journal of management information systems, 19(4), 9-30. doi: $10.1080 / 07421222.2003 .11045748$

Diamantopoulos, A., \& Winklhofer, H. M. (2001). Index construction with formative indicators: An alternative to scale development. Journal of marketing research, 38(2), 269-277. doi:10.1509/jmkr.38.2.269.18845

Dias-Trindade, S., \& Moreira, J. A. (2019). Pedagogical Scenarios Enriched with Audiovisual Technologies and Their Impact on the Promotion of the Learning Skills of Inmate Students in Portugal. Digital Education Review, 35, 97-110.

Evans, J. C., Yip, H., Chan, K., Armatas, C., \& Tse, A. (2020). Blended learning in higher education: professional development in a Hong Kong university. Higher Education Research \& Development, 1-14. doi: 10.1080/07294360.2019.1685943

Falk, R. F., \& Miller, N. B. (1992). A primer for soft modeling. University of Akron Press.

Fernández-Quero, J. L. (2021). El uso de las TIC como paliativo de las dificultades del aprendizaje en las ciencias sociales. Digital Education Review, (39), 213-237.

Fichten, C., Olenik-Shemesh, D., Asuncion, J., Jorgensen, M., \& Colwell, C. (2020). Higher Education, Information and Communication Technologies and Students with Disabilities: An Overview of the Current Situation. In Improving Accessible Digital Practices in Higher Education (pp. 21-44). Palgrave Pivot, Cham. doi:10.1007/978-3-030-37125-8_2 
Fuller, C. M., Simmering, M. J., Atinc, G., Atinc, Y., \& Babin, B. J. (2016). Common methods variance detection in business research. Journal of Business Research, 69(8), 3192-3198. doi:10.1016/ j.jbusres.2015.12.008

Gandolfi, E., Ferdig, R. E., \& Kratcoski, A. (2021). A new educational normal an intersectionality-led exploration of education, learning technologies, and diversity during COVID-19. Technology in Society, 66, 101637.

Gunn, C. (2010). Sustainability factors for e-learning initiatives. ALT-J, 18(2), 89-103. doi: 10.1080/09687769.2010.492848

Hadullo, K., Oboko, R., \& Omwenga, E. (2018). Status of e-learning Quality in Kenya: Case of Jomo Kenyatta University of Agriculture and Technology Postgraduate Students. The International Review of Research in Open and Distributed Learning, 19(1), 138-160. doi:10.19173/irrodl.v19i1.3322

Hair Jr, J. F., Sarstedt, M., Ringle, C. M., \& Gudergan, S. P. (2017). Advanced issues in partial least squares structural equation modeling. Sage Publications.

Hassanzadeh, A., Kanaani, F., \& Elahi, S. (2012). A model for measuring e-learning systems success in universities. Expert Systems with Applications, 39(12), 10959-10966. doi:10.1016/ j.eswa.2012.03.028

Henseler, J., Ringle, C. M., \& Sarstedt, M. (2015). A new criterion for assessing discriminant validity in variancebased structural equation modeling. Journal of the academy of marketing science, 43(1), 115-135. doi: $10.1007 /$ s11747-014-0403-8

Herzberg, F., Mausner, B., \& Snyderman, B. S. (1959). The Motivation to Work. New York: Wiley.

Ifinedo, P. (2017). Examining students' intention to continue using blogs for learning: Perspectives from technology acceptance, motivational, and social-cognitive frameworks. Computers in Human Behavior, 72, 189-199. doi:10.1016/j.chb.2016.12.049

Johnson, A., Galloway, C., Friedlander, E., \& Goldenberg, C. (2019). Advancing educational quality in Rwanda: Improving teachers' literacy pedagogy and print environments. International Journal of Educational Research, 98, 134-145. doi:10.1016/j.ijer.2019.08.016

Jung, I. (2011). The dimensions of e-learning quality: from the learner's perspective. Educational Technology Research and Development, 59(4), 445-464. doi:10.1007/s11423-010-9171-4

Kang, Y. S., \& Lee, H. (2010). Understanding the role of an IT artifact in online service continuance: An extended perspective of user satisfaction. Computers in Human Behavior, 26(3), 353-364. doi:10.1016/j.chb.2009.11.006

Kettunen, J. (2008). A conceptual framework to help evaluate the quality of institutional performance. Quality Assurance in Education, 16(4), 322-332. doi:10.1108/09684880810906472

Khan, I. U., Hameed, Z., Yu, Y., \& Khan, S. U. (2017). Assessing the determinants of flow experience in the adoption of learning management systems: the moderating role of perceived institutional support. Behaviour \& Information Technology, 36(11), 1162-1176. doi:10.1080/0144929X.2017.1362475

Kim, K., Trimi, S., Park, H., \& Rhee, S. (2012). The impact of CMS quality on the outcomes of e-learning systems in higher education: an empirical study. Decision Sciences Journal of Innovative Education, 10(4), 575-587. doi:10.1111/j.1540-4609.2012.00360.x

Kim, H. J., Lee, J. M., \& Rha, J. Y. (2017). Understanding the role of user resistance on mobile learning usage among university students. Computers \& Education, 113, 108-118. doi:10.1016/ j.compedu.2017.05.015

Kurt, Ö. E. (2019). Examining an e-learning system through the lens of the information systems success model: Empirical evidence from Italy. Education and Information Technologies, 24(2), 1173-1184. doi:10.1007/s10639-018-9821-4

Lee, Y., Hsieh, Y., \& Ma, C. (2011). A model of organisational employees' e-learning systems acceptance. Knowledge-Based Systems, 24(3), 355-366. doi:10.1016/j.knosys.2010.09.005 
Li, Y., Duan, Y., Fu, Z., \& Alford, P. (2012). An empirical study on behavioural intention to reuse e-learning systems in rural China. British Journal of Educational Technology, 43(6), 933-948. doi:10.1111/ j.1467-8535.2011.01261.x

Lin, W. S. (2012). Perceived fit and satisfaction on web learning performance: IS continuance intention and task-technology fit perspectives. International Journal of Human-Computer Studies, 70(7), 498-507. doi:10.1016/j.ijhcs.2012.01.006

Martínez-Argüelles, M. J., \& Batalla-Busquets, J. M. (2016). Perceived service quality and student loyalty in an online university. The International Review of Research in Open and Distributed Learning, 17(4), 264-279. doi:10.19173/irrodl.v17i4.2518

McGill, T. J., \& Klobas, J. E. (2009). A task-technology fit view of learning management system impact. Computers \& Education, 52(2), 496-508. doi:10.1016/j.compedu.2008.10.002

McGill, T. J., Klobas, J. E., \& Renzi, S. (2014). Critical success factors for the continuation of e-learning initiatives. The Internet and Higher Education, 22, 24-36. doi:10.1016/j.iheduc.2014.04.001

MCIU (Ministerio de Ciencia, Innovación y Universidades) (2019). Datos y cifras del sistema universitario español. Publicación 2018-2019. Accessed 13 September 2020. http://www.educacionyfp.gob.es/dam/ jer:2af709c9-9532-414e-9bad-c390d32998d4/datos-y-cifras-sue-2018-19.pdf

Mohammadi, H. (2015). Investigating users' perspectives on e-learning: An integration of TAM and IS success model. Computers in Human Behavior, 45, 359-374. doi:10.1016/j.chb.2014.07.044

Mushtaq, N., \& Malik, A. B. (2018). The Role of Public and Private Universities of Pakistan as Learning Organization. Journal of Research in Social Sciences, 6(1), 277-290. https://search.proquest.com/ openview/03a356a0cdc150f11a900e716a06475c/1?pq-origsite $=$ gscholar $\& \mathrm{cbl}=2030756$

Naidu, P., \& Derani, N. E. S. (2016). A comparative study on quality of education received by students of private universities versus public universities. Procedia Economics and Finance, 35, 659-666. doi: $10.1016 / \mathrm{S} 2212-5671(16) 00081-2$

Nijman, D. J., \& Gelissen, J. (2011). Direct and indirect effects of supervisor support on transfer of training. In Supporting workplace learning (pp. 89-106). Springer, Dordrecht.

Petter, S., \& McLean, E. R. (2009). A meta-analytic assessment of the DeLone and McLean IS success model: An examination of IS success at the individual level. Information \& Management, 46(3), 159-166. doi: $10.1016 /$ j.im.2008.12.006

Pham, L., Williamson, S., \& Berry, R. (2018). Student perceptions of e-learning service quality, e-satisfaction, and e-loyalty. International Journal of Enterprise Information Systems, 14(3), 19-40. doi:10.4018/ IJEIS. 2018070102

Podsakoff, P. M., MacKenzie, S. B., Lee, J.-Y., \& Podsakoff, N. P. (2003). Common method biases in behavioral research: A critical review of the literature and recommended remedies. Journal of Applied Psychology, 88(5), 879-903. doi:10.1037/0021-9010.88.5.879

Prensky, M. (2013). Enseñar a nativos digitales. México: SM Ediciones.

Pucciarelli, F., \& Kaplan, A. (2016). Competition and strategy in higher education: Managing complexity and uncertainty. Business Horizons, 59(3), 311-320. doi:10.1016/j.bushor.2016.01.003

Raposo-Rivas, M., \& de la Serna, M. C. (2019). Technology to Improve the Assessment of Learning. Digital Education Review, (35).

Rey, E. D. \& Romero, L. (2004). Competition between public and private universities: quality, prices and exams. Documentos de trabajo. Economic series (Universidad Carlos III. Departamento de Economía), 23, 1-24. https://ideas.repec.org/p/cte/werepe/we046423.html

Queiros, D. R., \& de Villiers, M. R. (2016). Online learning in a South African higher education institution: Determining the right connections for the student. The International Review of Research in Open and Distributed Learning, 17(5), 165-185. doi:10.19173/irrodl.v17i5.2552

Tashakkori, A., \& Teddlie, C. (2010). Sage handbook of mixed methods in social and behavioral research. SAGE publications. 
Uppal, M. A., Ali, S., \& Gulliver, S. R. (2018). Factors determining e-learning service quality. British Journal of Educational Technology, 49(3), 412-426. doi:10.1111/bjet.12552

Velásquez, R. M. A., \& Lara, J. V. M. (2021). Knowledge management in two universities before and during the COVID-19 effect in Peru. Technology in Society, 64, 101479.

Vernadakis, N., Antoniou, P., Giannousi, M., Zetou, E., \& Kioumourtzoglou, E. (2011). Comparing hybrid learning with traditional approaches on learning the Microsoft Office Power Point 2003 program in tertiary education. Computers \& Education, 56(1), 188-199. doi:10.1016/j.compedu.2010.08.007

Wang, H. C., \& Chiu, Y. F. (2011). Assessing e-learning 2.0 system success. Computers \& Education, 57(2), 1790-1800. doi:10.1016/j.compedu.2011.03.009

Wang, Y. S., \& Liao, Y. W. (2008). Assessing eGovernment systems success: A validation of the DeLone and McLean model of information systems success. Government information quarterly, 25(4), 717-733. doi:10.1016/j.giq.2007.06.002

Wang, Y. S., Wang, H. Y., \& Shee, D. Y. (2007). Measuring e-learning systems success in an organisational context: Scale development and validation. Computers in Human Behavior, 23(4), 1792-1808. doi:10.1016/j.chb.2005.10.006

Wilkinson, R., \& Yussof, I. (2005). Public and private provision of higher education in Malaysia: A comparative analysis. Higher Education, 50(3), 361-386. doi:10.1007/s10734-004-6354-0

Williams, C., \& Beam, S. (2019). Technology and writing: Review of research. Computers \& Education, 128, 227-242. doi:10.1016/j.compedu.2018.09.024

Wu, H. Y., \& Lin, H. Y. (2012). A hybrid approach to develop an analytical model for enhancing the service quality of e-learning. Computers \& Education, 58(4), 1318-1338. doi:10.1016/j.compedu.2011.12.025

Yakubu, N., \& Dasuki, S. (2018). Measuring e-learning success in developing countries: applying the updated DeLone and McLean model. Journal of Information Technology Education: Research. http:// shura.shu.ac.uk/21526/ 